UDC 39:2

\title{
INTERRELATION BETWEEN ETHNIC CULTURE AND RELIGION: GENERAL AND SPECIFIC CONNECTIONS
}

\author{
(C) Vachit Kh. Akaev, Naida M. Vagabova
}

\author{
Comprehensive Research Institute named after H.I. Ibragimov of the Russian Academy of \\ Sciences, Grozny, Chechen Republic, Russian Federation; \\ Dagestan State University, Makhachkala, Republic of Dagestan, Russian Federation \\ akaiev@mail.ru
}

The interrelation between "ethnic culture" and "religion" is conceived, identifying both general and specific aspects. Ethnic culture is regarded as a result of the activities of representatives of the ethnic group, which allowed them to communicate, consolidate, focusing on the search for prospects for their development. Traditional culture, national culture and mass culture are correlated with ethnic culture. Despite some proximity of these phenomena, they differ from each other, and in the course of their comparison, general and special aspects are distinguished. It is justified that religion is an integral part of ethnic culture, forming a certain worldview among the ethnic group, raising its spiritual level. The spiritual development of the ethnic group, along with folklore plots, based on religious values, are preserved in the ethnic culture itself. Historically outgrowing the volume of ethnic culture, religion spreads among different peoples, ceasing to be a part of the culture of an individual ethnic group, but at the same time becoming a factor in the unification of various cultural characteristics. When considering the interrelation between religion and nation, their specific relationship should be noted. Thus, being a component of national culture, religion takes an active part in the formation of national identity, spiritual consolidation and unity of people.

Key words: culture, ethnic culture, national culture, religion, Islam, Sufism, Wahhabism, North Caucasus.

\section{[В.Х. Акаев, Н.М. Вагабова Взаимосвязь этнической культуры и религии: общие и специфиче- ские связи]}

Осмысливается взаимосвязь понятий «этническая культура» и «религия», выявляя как общие, так и специфические аспекты. Этническая культура рассматривается как результат деятельности представителей этноса, позволяющая им общаться, консолидироваться, ориентируясь на поиск перспектив их развития. С этнической культурой соотносятся традиционная культура, национальная культура, массовая культура. Несмотря на некую близость этих феноменов, они отличаются друг от друга, а в ходе их сопоставления выделяются общие и особенные аспекты. Обосновывается положение о том, что религия является составной частью этнической культуры, формирующая у этноса определенное мировосприятие, повышая его духовный уровень. Духовное развитие этноса, наряду с фольклорными сюжетами, опираясь на религиозные ценности, сохраняются в самой этнической культуре. Исторически перерастая объем этнической культуры, религия распространяется среди разных народов, переставая быть частью культуры отдельно взятого этноса, но становясь при этом фрактором объединения различных культурных особенностей. При рассмотрении соотношения религии и нации, следует отметить их специфическую связь. Так, будучи компонентом национальной культуры, религия принимает активное участие в формировании национального самосознания, духовной консолидации и единению людей.

Ключевые слова: культура, этническая культура, национальная культура, религия, ислам, суфризм, ваххабизм, Северный Кавказ.

Vachit Kh. Akaev - Ph.D. (Advanced Doctorate) in Philosophy, Professor, Chief Research Worker, Comprehensive Research Institute named after H.I. Ibragimov of the Russian Academy of Sciences, Grozny, Chechen Republic, Russian Federation.

Naida M. Vagabova - Ph.D. in Philosophy, Dagestan State University, Makhachkala, Republic of Dagestan, Russian Federation. 
Акаев Вахит Хумидович - доктор фрилософрских наук, профрессор, главный научный сотрудник, Комплексный научно-исследовательский институт им. Х.И. Ибрагимова Российской Академии Наук,. Грозный, Чеченская Республика, Российская Федерация.

Вагабова Наида Муратовна - кандидат фрилософских наук, Дагестанский государственный университет, г. Махачкала, республика Дагестан, Российская Федерация.

The formation of ethnic culture takes place in the course of the multifaceted activities of representatives of the ethnic group (ethnophor) aimed at creating material and spiritual values necessary for their existence, intra-ethnic communication and consolidation. During this creative process, ethnophors are based on the ethnic language, customs, traditions, mental characteristics, worldview. Ethnic culture is necessary for them to find a better share of life, as well as for adapting to local-regional socio-economic processes. At the early stage of the development of the ethnic group, culture divides people into "their own" and "the others," thereby creating their cultural identification. The distinction between "their own" and "the others" is made not only in the external, anthropological appearance, but also in language, clothing, household habits, food, wedding ceremony, behavior, housing, sculpture and other hand-made artifacts.

Ethnic culture includes more complex structural components: customs, traditions, rites performed during holidays, weddings, funerals. An important place in the structure of ethnic culture is occupied by folk dances, music, songs, legends, traditions, myths. These components are different among different peoples, for example, the mythical legend "The Poem of Gilgamesh" is a folklore-cultural artifact of ancient Sumerians. The myth of the hero Prometheus was composed by the ancient Greeks. In the folklore of the peoples of the North Caucasus, the "Nart saga" occupies the key place, and the most voluminous myth among the peoples of the world is the Kyrgyz epic of "Manas," etc. Myths describe the exploits of folk heroes aimed at uniting a disparate ethnic group or ethnic groups, they describe the struggle against violence, overcoming barbarism, the triumph of good over evil, the achievement of contradictory universal, civilizational development. They are morally instructive, spiritually exalting over the cruel world, directing to new meanings of existence, orienting representatives of the ethnic group, an individual person towards more perfect society.

Mythological systems that arose in ancient times among different peoples in a transformed form retain their place in traditional cultures. Myths correlate with modernity, which allows you to determine the vector of modern ethnocultural, civilizational development, becoming the subject of cultural, philosophical analysis.

The concepts of "ethnic culture" and "culture of an ethnic group" differ. Culture of an ethnic group incorporates not only purely ethnic components, but also values borrowed from the cultures of other peoples. Culture of an ethnic group contains both traditional cultural values and modern scientific and technical achievements, becoming common to the cultures of modern peoples. Ethnic culture is always traditional, although, as a system of material and spiritual values, it goes through the changes under the influence of social crises, scientific and technological achievements. Ethnic culture should be distinguished from national culture. As is known, a nation is a more complex and later social formation than an ethnos. With its formation, ethnic groups do not disappear, they continue their existence in the nation, more developed social order that has a high density of communications.

National culture, along with common language, household, economy and the State, stands out as one of the leading components of a social system that provides it much more opportunities for differentiation, development. In it, the ethnic signs of culture do not disappear without a trace, for they continue to live their lives separately from the dominant 
nation. For example, Jews, Armenians, Russians, Arabs, Croats, Mexicans, etc., living in various States for a long time, often retain their ethnic traits, religious values, attachment to their native ethnos. But in their main socio-cultural parameters, they relate to the State of which they become citizens.

Ethnic and traditional cultures with their own special features differ. Traditional culture takes into account the historical values developed by the people in the course of historical development. It is often used in the meaning of folk culture, it is always stable, changes occur in it slowly. Tales, traditions, images of heroes and other values are important components of folk culture. Traditional culture includes not only the components of one ethnic group, but also a number of components of other ethnic groups taking part in its formation.

High (elitist) culture and folk culture (folklore) are interconnected; the first one is formed on the basis of the second one. Through specialization and professionalization, certain components of folk culture are transformed into an elitist culture, represented by a select, professionally trained circle of people. In this regard, mass culture should also be distinguished, the components of which are simplified in terms of sense and art, and therefore accessible to everyone, becoming common. Mass culture is active, aggressive, often displaces both high and folk culture, becoming dominant itself. In society, many subcultures of various groups are formed that determine their lifestyle, contacts and worldview.

The spiritual development of the ethnic group, along with folklore storylines, is based on religious values that persist in the ethnic culture itself. "In traditionalist societies, religion and myth played a dominant role in culture" [2, p. 253]. Very often these religious values outgrow ethnic culture, they are included in the cultures of other peoples, forming a syncretic spiritual space, expanding a heterogeneous world perception. Religion professed by an ethnos is a definite result of its spiritual, mental activity. This is an initial attempt to respond to the frightening natural fears of the ethnic group. Religious values created by a separate ethnic group are mastered by other ethnic groups, thereby forming a common irrational world, which is subordinated to natural spontaneous processes controlled by a powerful, transcendental force. The scientific and materialistic explanation of the emergence of religion does not exhaust questions of its origin. Religion, relying on fantasy, imagination, tries to explain natural phenomena incomprehensible to people, by involving mysticism, an irrational state, and the fears arising from this are endowed with divine powers. The imagination of a person works here, the images created by him often contain ethnic characteristics, features. In the modern world, the attitude towards religion has fundamentally changed, fears among people have been minimized, although natural disasters cause no less fear than in ancient times.

When considering the interrelation between religion and nation, their specific relationship should be noted. Thus, being a component of national culture, religion takes an active part in the formation of national identity, spiritual consolidation and unity of people. Something similar happened in the United States. For example, in America, everyone should have faith and it does not matter which one, on this occasion, President Eisenhower stated that our form of government does not make the slightest sense if we cease to take into account religion"[3, p. 163]. In modern, post-atheist Russia, the roles of Orthodoxy, Islam, etc., have increased significantly. Religion actively influences the formation of the ethnic and even political identity of the peoples of the country.

The development of ethnic culture often entails the formation of religious subcultures, uniting small groups of people who adhere to different religious ideologies, corresponding practices. Similar processes are observed in the North Caucasus. Thus, peoples of the region differ in the presence of various ethnic, linguistic, mental characteristics that are different from each other, forming certain types of identities. At the same time, many of them 
have a common spiritual basis, associated, for example, with practice of Sunni, which has its own forms of existence in the region: folk Islam, Sufi Islam. In Dagestan, Islam is represented by Sufi tariqas - the Naqshbandi, the Kadiriya and the Shadhili, and in Chechnya and Ingushetia there are two Sufi tariqas, they are the Naqshbandi, the Kadiriya [1, c.131; 4], divided into many small groups, more than 32 types. They arose in the 19th-20th centuries, their founders were Dagestan and Chechen Sufis, Wali, many of whom were repressed, exiled, accused of fanaticism, obscurantism, rebellion, anti-state activity. In Chechnya, Ingushetia, the places of their burials have been turned into ziyarats (mausoleums), today they are all reconstructed, the trails, and the roads leading to them are civilized. Many Muslim believers visit these burial sites. The local religious subculture is common to the Chechens and the Ingush, forming an important part of the ethnic cultures of the Muslims of the region.

Of course, the ethnic culture of the peoples of the North Caucasus, having pronounced features of conservatism, is influenced by modernity, which leads to the transformation of its periphery, with the strength of a common core. So, since the 90s, the North Caucasus has been penetrated by such a religious and political trend of Islam, called "Wahhabism," which represents an alternative to local traditional religious values, including the values of ethnic culture. Its impact on regional Muslim culture gave rise to a situation of confrontation between supporters of traditionalism and "innovators" who advocate the purity of Islam. The latter accused traditionalists of misconception, distortion of Islam, and therefore tried to re-Islamize the peoples of the North Caucasus, making obvious attempts to destroy common religious traditions such as visiting the burial sites of Sufi teachers, the cult of saints.

Supporters of Wahhabism introduced new cult practices into the Islamic culture of the region, imposed an appropriate dress code and appearance on Muslims. Influencing young people, they tried to change their attitude to entrenched traditions, ideologically and politically they oriented people to the countries where there is "pure" Islam. The contradictions between innovators and traditionalists have reached an antagonistic character. Such a situation required the implementation of measures of spiritual, cultural and political opposition to manifestations of religious extremism, rejected by representatives of traditional Islamic culture, adapted to the all-Russian socio-cultural reality.

Thus, a comparative analysis of a particular material makes it possible to conclude that the current situation of the interrelation between ethnic culture and religion requires the formation in the public consciousness of the need to ensure the continuity of positive socio-cultural experience based on national idea, domestic traditions, cultural values. The humanistic orientation of ethnic culture and religion, the formation of a high level of communicative culture can and should heal from all evil. This is a great task waiting for its solution.

\section{Лumepamypa}

1. Акаев В.Х. Суфийская культура на Северном Кавказе: теоретические и практические аспекты / Отв. ред. Г.В. Драч. Грозный: Книжное изд-во, 2011.

2. Степин В.С. Цивилизация и культура. СПб.: СПб. 2011.

3. Хантингтон С. Кто мы? Вызовы американской национальной идентичности. М.: АСТ; Транзиткнига, 2004.

4. Akayev V.H. Islam in modern Russia: interrelation of traditions and innovations // Научный альманах стран Причерноморья. 2015. № 3. http://science-almanac.ru

5. Akaev V. Ethnocultural diversity and consolidation of Caucasus people unity: theoretic-methodologic analysis // Научный альманах стран Причерноморья. 2016. № 3. http://science-almanac.ru 


\section{References}

1. Akaev V.Kh. Sufiiskaia kultura na Severnom Kavkaze: teoreticheskie i prakticheskie aspekty. [Sufi culture in the North Caucasus: theoretical and practical aspects]. Ed.-in-chief G.V. Drach. Grozny: Book Publishing House, 2011 (in Russian).

2. Stepin V.S. Tsivilizatsiia i kultura. [Civilization and culture]. Saint Petersburg: Saint Petersburg. 2011 (in Russian).

3. Huntington S. Vyzovy amerikanskoi natsionalnoi identichnosti. [Who are we? Challenges of American national identity]. Moscow: AST; Tranzitkniga, 2004 (in Russian).

4. Akayev V.H. Islam in modern Russia: interrelation of traditions and innovations. Science almanac of Black Sea region countries. 2015. No.3.

5. Akaev V. Ethnocultural diversity and consolidation of Caucasus people unity: theoretic-methodologic analysis. Science almanac of Black Sea region countries. 2016. No.3. 